\title{
PENERAPAN METODE DISKUSI KELOMPOK UNTUK MENINGKATKAN HASIL BELAJAR IPA DI SEKOLAH DASAR NEGERI 1 SUKADANA
}

\author{
Oleh : \\ Nengah Kelirik \\ SD Negeri 1 Sukadana \\ Email: nengah_kelirik@yahoo.com
}

\begin{abstract}
ABSTRAK
Penelitian ini bertujuan untuk meningkatkan hasil belajar IPA siswa kelas V SD Negeri 1 Sukadana melalui penerapan metode diskusi kelompok. Penelitian ini adalah penelitian tindakan kelas yang dilakukan dalam dua siklus dengan subjek penelitian adalah siswa kelas V SD Negeri 1 Sukadana pada tahun pelajaran 2013/2014. Data dikumpulkan dengan tes yang diadakan pada setiap akhir siklus. Data dianalisis secara deskriptif untuk menjelaskan peningkatan hasil belajar sebelum dan setelah penerapan metode diskusi kelompok. Hasil penelitian menunjukkan bahwa nilai rata-rata hasil belajar siswa pada refleksi awal sebesar 68,39 meningkat 1,3 pada siklus I menjadi 69,68 kemudian meningkat sebesar 11,61 menjadi 81,29 pada siklus II. Daya serap meningkat 1,3\% dari 68,39\% pada refleksi awal menjadi $69,68 \%$ pada siklus I dan mengalami peningkatan sebesar $11,61 \%$ menjadi $81,29 \%$ pada siklus II. Ketuntasan belajar secara klasikal juga meningkat $9,7 \%$ dari refleksi awal sebesar 54,84\% menjadi $64,52 \%$ dan sebesar $35,48 \%$ sehingga menjadi $100 \%$ pada siklus II. Penerapan metode diskusi kelompok telah berhasil meningkatkan hasil belajar IPA siswa kelas V SD Negeri 1 Sukadana.
\end{abstract}

Kata Kunci : diskusi kelompok, hasil belajar

\begin{abstract}
The aim of this study was to improve students' learning achievement at class V SD Negeri 1 Sukadana through the use of group discussion method in the science subject. The subject involved were all students of fifth grade at SD negeri 1 Sukadana in the academic year 2013/2014 with the total number of 31 students. Data were collected by test to describe improvement cycle by cycle. Data were analized dscritipely. The result shows that the average of student learning achievement in the early reflection, 68,39, by the end of the first cycle increased to 69,68, and then by the end of the second cycle, increased to 81,29. Absorption of subject matter in in the early reflection, 68,39\%, by the end of the first cycle increased to 69,68\%, and then by the end of the second cycle, increased to $81,29 \%$. Classical mastery level in the early reflection $54,84 \%$, by the end of the


first cycle increased to $65,52 \%$, and then by the end of the second cycle, increased to $100 \%$. However, the implementation of the group discussion method is found to improve the student' learning achievement.

Keywords: learning achievement, group discussion method

\section{A. PENDAHULUAN}

Peningkatan mutu pendidikan merupakan sebuah harapan yang harus diwujudkan oleh pemerintah dalam bentuk hasil yang nyata. Bertolak dari kondisi ini pemerintah memberikan perhatian serius pada bidang pendidikan, terbukti dengan berbagai terobosan yang telah dilakukan. Keseriusan pemerintah ini diwujudkan dalam berbagai bentuk seperti peluncuran program wajib belajar sembilan tahun, peningkatan kompetensi guru melalui berbagai kegiatan seperti seminar, penataran dan berbagai pelatihan. Hal ini dilakukan oleh pemerintah dalam rangka memaksimalkan peranan guru dalam mengelola pendidikan. Peningkatan kualifikasi dan kesejahteraan guru setidaknya akan memberikan imbas yang positif dalam pendidikan. Namun demikian, kondisi di lapangan memberikan fakta yang berbeda.

Kualitas pendidikan Indonesia masih jauh jika dibandingkan dengan negara-negara di dunia. Selain itu berbagai kendala ditemukan khususnya dalam pembelajaran. Ini merupakan faktor penghambat tercapainya tujuan tersebut. Kendala-kendala yang menghambat pencapaian tujuan pendidikan di antaranya; (1) kurangnya minat dan motivasi siswa terhadap mata pelajaran Ilmu Pengtahuan Alam karena dipandang sangat rumit dan kompleks, (2) terdapat permasalahan pada penerapan metode pembelajaran, dimana metode yang diterapkan kurang variatif, guru hanya menerapkan metode ceramah (bersifat konvensional) dan pemberian tugas yang pada ujungnya tidak mampu meningkatkan keaktifan siswa, (3) kurangnya variasi metode pembelajaran menyebabkan guru mendominasi kegiatan belajar dan siswa bersifat pasif hanya mendengar materi yang disampaikan oleh guru selama peroses pembelajaran berlangsung, sehingga membosankan bagi siswa. Untuk mengatasi masalah tersebut, maka seorang guru harus mampu menciptakan iklim belajar yang menarik di kelas (sekolah). 
Pembelajaran yang menarik dan inovatif membuat siswa semakin tertarik dan menumbuhkan minat untuk belajar dan memberikan perhatian yang lebih terhadap pelajaran. Sesungguhnya minat siswa perlu menjadi fokus perhatian karena minat memegang peranan yang penting. Hal ini sejalan dengan Slameto (2003) yang mengatakan bahwa siswa yang memiliki minat terhadap subjek tertentu cenderung untuk memberikan perhatian yang lebih besar terhadap subjek tersebut.

Hasil observasi awal di Kelas V Sekolah Dasar Negeri 1 Sukadana menunjukkan hasil yang belum maksimal dalam proses pembelajaran. Dari jumlah siswa sebanyak 31 orang, hanya 13 orang siswa (40\%) di antaranya yang aktif dalam proses pembelajaran, sedangkan lainnya cenderung pasif. Selain itu bila dilihat dari hasil ulangan harian didapatkan data rata-rata hasil belajar siswa (M) sebesar 68 dan ketuntasan belajar (KB) hanya mencapai 30\% (10 orang siswa). Hal ini menunjukkan bahwa hasil dan keaktifan siswa sangat rendah. Apabila kondisi ini tidak diatasi, maka pencapaian tujuan pendidikan pada umumnya dan hasil belajar siswa khususnya untuk mata pelajaran Ilmu Pengetahuan Alam (IPA) akan sangat mustahil untuk ditingkatkan. Rendahnya hasil belajar IPA disebabkan karena kurangnya minat, motivasi dan keaktifan selama proses pembelajaran. Hal ini terbukti pada pembelajaran IPA siswa belum menunjukkan peran yang masimal baik dalam bertanya atau menjawab pertanyaan yang diajukan guru kepada siswa. Di samping itu siswa sering tidak menyelesaikan tugas-tugas yang dibebankan kepadanya secara individual.

Dalam upaya meningkatkan kualitas sumber daya manusia melalui usaha meningkatkan hasil belajar IPA seperti permasalahan yang telah dipaparkan di atas ada beberapa alternatif pemecahan antara lain: 1) pembelajaran dengan memaksimalkan penggunaan media pembelajaran, 2) membuat kelompok belajar dan memanfaatkan lingkungan sebagai sumber belajar siswa, 3) menggunakan metode pembelajaran yang bervariasi disesuaikan dengan karaktersitik materi pembelajarn, 4) memaksimalkan metode diskusi kelompok yang didahului dengan pemberian tugas dalam pembelajaran, 5) meningkatkan peran siswa dalam pembelajaran. 
Beberapa langkah di atas dapat ditempuh sebagai usaha untuk menciptakan kondisi pembelajaran yang efektif dan menarik. Terkait dengan uraian di atas, peneliti memilih salah satu langkah alternatif sebagai solusi pembelajaran yaitu penguunaan metode diskusi kelompok. Metode diskusi merupakan siasat untuk menyampaikan bahan pelajaran yang melibatkan siswa secara aktif untuk membicarakan dan menemukan alternatif pemecahan suatu topik bahasan yang bersifat problematis, Sanjaya (dalam Abimanyu, 2008). Metode ini memiliki banyak kelebihan seperti: (1) membantu siswa berpikir berdasarkan sudut pandang suatu subyek bahasan dengan memberi kebebasan siswa untuk berfikir, (2) membantu siswa mengevaluasi logika dan bukti-bukti bagi posisi dirinya atau posisi orang lain, (3) memberikan suatu kesempatan kepada siswa untuk memformulasikan penerapan suatu prinsip, (4) membantu siswa menyadari akan suatu problem dan memformulasikan dengan menggunakan informasi yang diperoleh dari bacaan atau ceramah, (5) menggunakan bahanbahan dari anggota lain dalam kelompoknya, dan (6) mengembangkan motivasi untuk belajar yang lebih baik (Zaini, dkk, 2004).

Bertolak dari paparan di atas, maka diyakini bahwa hasil belajar IPA siswa kelas V Sekolah Dasar Negeri 1 Sukadana tahun pelajaran 2013/2014 akan dapat ditingkatkan melalui penerapan metode diskusi kelompok.

\section{B. METODE PENELITIAN}

Penelitian ini merupakan penelitian tindakan kelas (PTK). Subyek penelitian ini adalah siswa Kelas V Sekolah Dasar Negeri 1 Sukadana Kecamatan Kubu Kabupaten Karangasem tahun pelajaran 2013/2014 yang berjumlah 31 orang, terdiri dari 12 orang laki-laki dan 19 orang perempuan. Objek Penelitian ini adalah metode diskusi kelompok dan hasil belajar. Kegiatan penelitian dirancang dalam pola siklus. Masing-masing siklus terdiri dari 4 (empat) tahapan seperti: (1) perencanaan, (2) indakan, (3) evaluasi/observasi, dan (4) refleksi

Metode pengumpulan data yang digunakan adalah metode tes. Tes berupa tes tertulis dalam bentuk soal objektif (bentuk pilihan ganda) dengan jumlah soal sebanyak 20 butir. Masing-masing soal memiliki empat jenis pilihan yaitu a, b, c, 
dan d. Penilaian dilakukan dengan memberikan nilai 1 pada siswa yang memberikan jawaban benar dan nilai 0 bagi siswa yang menjawab salah.

Data siswa yang terkumpul dalam penelitian dianalisis dengan statistik deskriptif. Pengolahan data meliputi pencarian rata-rata, daya serap, ketuntasan belajar. Rumus yang digunakan dalam mencari persentase hasil belajar Ilmu Pengetahuan Alam (IPA) adalah:

$$
\bar{X}=\frac{\sum X}{N}
$$

Keterangan:

$$
\begin{array}{ll}
\overline{\mathrm{X}} & =\text { Rata-rata skor hasil belajar siswa secara klasikal } \\
\sum \mathrm{X} & =\text { Jumlah seluruh skor hasil belajar siswa secara individu } \\
\mathrm{N} & =\text { Banyaknya siswa }
\end{array}
$$

(Sudjana, 2008)

Hasil belajar siswa dicari dengan menggunakan Daya Serap (DS) dan Ketuntasan Klasikal (KK). Daya Serap dihitung dengan rumus:

$$
\text { DS }=\frac{\text { Jumlah skor yang dicapai siswa }}{\text { Jumlah skor maksimum }} \times 100 \%
$$

Sedangkan ketuntasan belajar siswa secara klasikal (KK). Dapat dihitung dengan rumus:

$$
\mathrm{KB}=\frac{\text { Banyaknya siswa yang tuntas }}{\text { Banyak siswa yang ikut tes }} \times 100 \%
$$

Selanjutnya disesuaikan dengan PAP skala 5 dalam menentukan daya serap dan ketuntasan belajar. Ketuntasan yang dimaksudkan adalah ketuntasan pada siswa setelah mencapai nilai 70 secara individu sesuai dengan KKM yang ditetapkan serta ketuntasan kelas sebesar $80 \%$

\section{HASIL PENELITIAN DAN PEMBAHASAN}

\section{Hasil Penelitian}

Rangkuman hasil penelitian disajikan pada tabel 1 berikut. 
Tabel 1. Rangkuman Hasil Penelitian

\begin{tabular}{lccc}
\hline & Refleksi Awal & Siklus I & Siklus II \\
\hline Nilai Minimum & 50 & 60 & 70 \\
\hline Nilai Maksimum & 80 & 80 & 90 \\
\hline Banyak testi & 31 & 31 & 31 \\
\hline Total nilai & 2120 & 2160 & 2520 \\
\hline Rata-rata & 68,39 & 69,68 & 81,29 \\
\hline Standar Deviasi & 1,29 & 1,28 & 0,83 \\
\hline Daya serap & $68,39 \%$ & $69,68 \%$ & $81,29 \%$ \\
\hline Ketuntasan belajar & $54,84 \%$ & $64,52 \%$ & $100 \%$ \\
\hline
\end{tabular}

\section{Hasil Penelitian Refleksi Awal}

Rata-rata skor hasil belajar IPA pada refleksi awal I mencapai 68,39. Dari 31 orang siswa di Kelas V SD Negeri 1 Sukadana hanya 17 orang siswa mampu mencapai nilai sesuai dengan KKM sedangkan sebanyak 14 orang belum mencapai target yang telah ditetapkan. Dengan demikian ketuntasan klasikal baru tercapai sebsar 54,84\%. Mengacu pada hasil tersebut, maka rata-rata hasil belajar, daya serap dan ketuntasan belajar klasikal belum memenuhi target yang telah ditetapkan.

Kondisi seperti ini terjadi karena selama ini pembelajaran masih bersifat konvensional yang cenderung masih menggunakan metode yang monoton seperti ceramah. Suasana pembelajaran dirasakan kurang menarik, aktivitas pembelajaran dalam kelas cukup terbatas. Interaksi yang terjadi ketika pembelajaran berlangsung masih sangat minim. Bertolak dari permasalahan tersebut, guru sebaga organisator pembelajaran melakukan upaya sebagai bentuk usaha mengatasai permasalahan yang terjadi. Hal ini dilakukan dengan tujuan untuk menciptakan pembelajaran yang menarik dan kondusif sehingga tujuan pembelajaran dapat tercapai. Sejalan dengan hal tersebut, guru berupaya untuk mencapai target ketuntasan minimal (KKM) yang telah ditetapkan. Dengan demikian, maka diterapkan metode diskusi kelompok dapat meningkatkan hasil 
belajar Ilmu Pengetahuan Alam Kelas V Sekolah Dasar Negeri 1 Sukadana tahun pelajaran 2013/2014.

\section{Hasil Penelitian Siklus I}

Rata-rata skor hasil belajar IPA pada siklus I mencapai 69,68, daya serap (DS) diperoleh 69,68\%. Sedangkan Ketuntasan Belajar (KB) secara klasikal mencapai 64,52\%. Dari 31 orang siswa di Kelas V SD Negeri 1 Sukadana hanya 20 orang siswa mampu mencapai nilai sesuai dengan KKM sedangkan sebanyak 11 orang belum mencapai target yang telah ditetapkan. Dengan demikian ketuntasan klasikal baru ercapai sebsar 64,52\%. Mengacu pada hasil tersebut, maka rata-rata hasil belajar, daya serap dan ketuntasan belajar klasikal belum memenuhi target yang telah ditetapkan.

Merujuk hasil yang diperoleh pada siklus I, maka dilakukan refleksi untuk mengetahui kelemahan dan keunggulan. Refleksi ini sebagai bahan pertimbangan perbaikan pada siklus berikutnya. Hasil refleksi yang beraitan dengan kelemahan pelaksanaan siklus I adalah: 1) pelaksanaan diskusi kelompok kurang maksimal karena siswa kurang memanfaatkan waktu bekerja kelompok dengan baik, 2) Siswa kurang mampu mengambil suatu kesimpulan terhadap materi yang dipelajari, 3) Siswa sebagai wakil dalam kelompok masih sering mengabaikan tanggung jawab yang diberikan dalam kelompoknya sehingga kurang fokus pada saat mengerjakan tugas. Kelemahan-kelemahan dalam pelaksanaan siklus I, maka dilakukan langkah dengan mengoptimalkan kegiatan pada siklus II melalui berbaga kegiatan seperti: 1) Memaksimalkan pelaksanaan diskusi kelompok melalui tugas-tugas yang diberikan dalam kelompok, 2) Mengarahkan siswa untuk memaksimalkan pemanfaatan waktu dalam kerja kelompok, 3) Membimbing dan mengarahkan siswa dalam pengambilan kesimpulan sehingga siswa mampu berpendapat secara efektif, 4) Memaksimalkan peran siswa dalam kelompok sehingga lebih menumbsuhkan kesadaran terhadap tanggung jawab yang harus dilakukan oleh siswa dalam kelompoknya masing-masing.

Hasil Penelitian Siklus II 
Rata-rata hasil belajar siswa sebesar 81,29. Dengan demikian hasil belajar pada siklus II telah mencapai target kriteria ketuntasan maksimal (KKM) mata pelajaran IPA yang dtetapkan sebesar 70. Demikian pula pada ketuntasan kelas yang ditargetkan mencapai $80 \%$, pada siklus II ini apa yang menjadi target tersebut telah terpenuhi. Ini tercermin dari hasil yang dicapai sebesar $100 \%$. Dengan demikian dari 31 orang siswa yang mengikuti tes, seluruh siswa dapat dinyatakan tuntas dalam pembelajaran IPA.

Keberhasilan yang didapat dalam pelaksanaan siklus II dikarenakan beberapa hal berikut: (1) pelaksanaan diskusi kelompok melalui tugas-tugas yang diberikan dalam kelompok berjalan dengan maksimal sehingga siswa dapat terlibat secara penuh dalam diskusi, (2) siswa dapat menggunakan waktu dengan baik dalam kerja kelompok. sehingga membuka peluang berjalannya pembelajaran secara efektif, efisien, dan terkoordinasi, (3) bimbingan dan arahan guru membantu siswa dalam pengambilan kesimpulan sehingga siswa mampu berkomunikasi secara efektif, dan (4) setiap siswa berpartisipasi aktif dalam kelompok, sehingga lebih menumbuhkan dan meningkatkan kesadaran tanggung jawab yang dilakukan siswa dalam kelompoknya masing-masing.

Merujuk hasil refleksi tersebut, dapat ditegaskan bahwa pembelajaran lebih efektif dan maksimal pada siklus II dibandingkan dengan siklus I melalu optimalisasi kegiatan dan peran siswa dalam pembelajaran. Dengan demikian kegiatan pembalajaran dengan menggunakan metode diskusi kelompok dapat digunakan dalam kegiatan pembalajaran khususnya pembelajaran Ilmu Pendidikan Alam (IPA).

\section{Pembahasan}

Data hasil penelitian menunjukkan bahwa terjadi peningkatan hasil belajar siswa kelas V Sekolah Dasar Negeri 1 Sukadana tahun pelajaran 2013/2014 pada pembelajaran Ilmu Pengetahuan Alam (IPA). Peningkatan tersebut dapat dilihat dari nilai rata-rata hasil belajar pada refleksi awal mencpai 68,39 meningkat menjadi 69,68 pada siklus I dengan peningkatan sebesar 1,3. Selanjutnya mengalami peingkatan pada siklus II sebesar 11,61 sehingga tercapai angka rata- 
rata 81,29. Sejalan dengan itu, ketuntasan belajar juga mengalami peningkatan yang signifikan. Pada refleksi awal tercapai sebesar 54,84\% meningkat 9,7\% menjadi $64,52 \%$ pada siklus I dan mengalami peningkatan sebesar $35,48 \%$ pada siklus II sehingga tercapai ketuntasan $100 \%$.

Peningkatan terhadap hasil belajar maupun ketuntasan belajar secara klasikal pada pelajaran Ilmu Pengetahuan Alam (IPA) yang dicapai oleh siswa pada dasarnya dari penerapan metode diskusi kelompok secara optimal. Penerapan metode yang optimal ini memberikan pengaruh yang besar baik terhadap guru maupun siswa. Di samping dilatih untuk berpikir secara kritis dan cermat, dan analitis, siswa juga dihadapkan pada kemampuan untuk mampu memecahkan masalah baik secara individu maupun kelompok terhadap tugastugas yang dibebankan oleh guru. Metode diskusi kelompok yang diterapkan memberikan banyak kelebihan sehingga pembelajaran dapat dimaksimalkan. Kelebihan-kelebihan tersebut diantaranya: (1) memberikan peluang kepada siswa dalam pemecahan masalah secara bersama-sama, (2) meningkatkan rasa tanggungjawab siswa terhadap tugas-tugas yang dibebankan, (3) meningkatkan motivasi belajar karena dalam kelompok kemampuan siswa bersifat heterogen, (4) setiap anggota kelompok memiliki peluang yang sama dalam memberikan gagasan terhadap permasalahan yang sedang dihadapi, (5) setiap siswa dapat saling melengkapi (saling mengisi).

Hasil penelitian ini melengkapi apa yang telah ditemukan Oktapia (2014) dan Hangin (2014), yang hasil penelitiannya menunjukkan telah terjadi peningkatan aktivitas belajar siswa melalui penerapan metode diskusi kelompok pada pembelajaran IPA di SD dan juga penelitian yang lakukan oleh Robat (2014) dan Murwanti (2014), yang menunjukkan bahwa penerapan metode kelompok pada pembelajaran IPA SD mampu meningkatkan motivasi belajar siswa. Di samping itu, hasil penelitian ini menguatkan apa yang telah diperoleh oleh Ajung dkk (2013) bahwa penerapan metode kerja kelompok dalam pembelajaran IPA dapat meningkatkan hasil belajar siswa. 


\section{SIMPULAN DAN SARAN}

\section{Simpulan}

Penggunaan metode diskusi kelompok dapat meningkatkan hasil belajar Ilmu Pengetahuan Alam (IPA) pada siswa kelas V Sekolah Dasar Negeri 1 Sukadana tahun pelajaran 2013/2014. Ini terlihat dari adanya peningkatan perolehan nilai rata-rata, daya serap dan ketuntasan klasikal.

Nilai rata-rata hasil belajar siswa pada refleksi awal sebesar 68,39 dengan peningkatan 1,3 pada siklus I menjadi 69,68 kemudian mengalami peningkatan sebesar 11,61 sehingga menjadi 81,29 pada siklus II. Daya serap mengalami peningkatan sebesar 1,3\% dari 68,39\% pada refleksi awal menjadi 69,68\% pada siklus I dan mengalami peningkatan lagi sebesar $11,61 \%$ menjadi $81,29 \%$ pada siklus II. Sejalan dengan hal tersebut ketuntasan belajar secara klasikal juga terdapat peningkatan $9,7 \%$ dari refleksi awal sebesar 54,84\% menjadi $64,52 \%$ dan sebesar $35,48 \%$ sehingga menjadi $100 \%$ pada siklus II.

\section{Saran}

Berdasarkan temuan dalam penelitian tindakan kelas ini, dapat disarankan sebaga berikut: 1) Mengetahui bahwa penggunaan metode diskusi kelompok dapat meningkatkan hasil belajar dalam proses pembelajaran, maka disarankan agar para pendidik khususnya guru kelas (yang mengajar Ilmu Pengetahuan Alam/IPA) di Sekolah Dasar Negeri 1 Sukadana untuk menerapkan metode ini dalam proses pembelajaran, 2) Disarankan kepada para pendidik di Sekolah Dasar Negeri 1 Sukadana agar lebih meningkatkan pengelolaan pembelajaran dengan menggunakan metode yang variatif, 3) Kepada peserta didik di Sekolah Dasar Negeri 1 Sukadana agar dalam pembelajaran lebih kreatif sehingga interaksi belajar menjadi lebih tampak dan suasana belajar menjadi menarik serta menyenangkan, 4) Perlu dilakukan penelitian tindakan kelas lanjutan untuk menyempurnakan skenario pembelajaran dan menambah frekwensi siklusnya dengan harapan dapat memberikan sumbangan yang lebih berarti bagi dunia pendidikan, 5) Terbukti penggunaan metode diskusi kelompok cukup efektif 
dalam meningkatkan hasil belajar, maka diharapkan dapat diterapkan juga pada mata pelajaran lain.

\section{DAFTAR PUSTAKA}

Abimanyu, Soli, dkk. 2008. Strategi Pembelajaran (Bahan Ajar Cetak). Jakarta: Depdiknas.

Ajung, dkk. 2013. Penerapan Metode Kerja Kelompok Dalam Pembelajaran Ipa Kelas Iv Sdn 03 Kawan Kecamatan Sungai Betung. Jurnal Pendidikan dan Pembelajaran Vol 3, No 4.

Hangin, Helarina. 2014. Peningkatan Aktivitas Belajar Peserta Didik pada Pembelajaran IPA Menggunakan Metode Diskusi Kelompok di SD. Jurnal Pendidikan dan Pembelajaran Vol 3, No 12.

Hasan, Iqbal. 2002. Pokok-pokok Materi Metodelogi Penelitian \& Aplikasinya. Bogor: Ghalia Indonesia.

Murnawati, Katarina. 2013. Penggunaan Metode Diskusi Kelompok Untuk Meningkatkan Hasil Belajar Siswa dalam Pembelajaran IPA di SD. Jurnal Pendidikan dan Pembelajaran Vol 2, No 1.

Oktapia, Suryanty. 2014. Peningkatan Aktivitas Belajar Peserta Didik Melalui Metode Kerja Kelompok Pembelajaran IPA Kelas II SD. Jurnal Pendidikan dan Pembelajaran Vol 3, No 2.

Robat, Mateus. 2014. Peningkatan Motivasi Belajar Peserta Didik Menggunakan Metode Kelompok Pembelajaran IPA Kelas III SD. Jurnal Pendidikan dan Pembelajaran Vol 3, No 2.

Slameto. 2003. Belajar dan Faktor-faktor yang Mempengaruhinya. Jakarta: PT. Rineka Cipta.

Sudjana, Nana. 2008. Penilaian Hasil Proses Belajar Mengajar. Bandung: PT Remaja Rosdakarya.

Sugiyono. 2013. Metode Penelitian Pendidikan. Bandung: Alfabeta.

Zaini,dkk. 2004. Strategi Pembelajaran Aktif. Yogyakarta. 